Original Paper

\title{
Herbicides and salicylic acid applications caused alterations in total amino acids and proline contents of peanut cultivars
}

\author{
Khalaf Ali Fayez ${ }^{*, * *}$, Deya Eldeen Mohamed Radwan ${ }^{*}$, Asmaa Khalaf Mohamed", Abdelrahman \\ Mahmoud Abdelrahman* \\ *Botany Department, Faculty of Science, Sohag University, Egypt \\ ${ }^{* * *}$ Biology Department, Faculty of science, Taif University, Saudi Arabia
}

Rec. 5 Jun, 2011 Accpt. 21 Jun, 2011

\begin{abstract}
The influence of exogenous application of herbicides and salicylic acid (SA) on total amino acids and proline contents of two peanut cultivars was studied. Fusilade and basagran treatments caused an increase in the contents of free amino acids with 0.5 field dose $(0.5$ FD) and 1 FD but decreased with $1.5 \mathrm{FD}$. SA affects greatly the leaf amino acids contents with or without herbicides. Spraying of SA one day before fusilade treatment caused a significant increase in amino acids contents of Giza 5 (G5) and Giza 6 (G6) comparing with that of the corresponding controls. SA treatments, mixed with or sprayed before basagran application, caused no significant changes in leaf amino acids content compared to the control. G6 cultivar contained almost doubled amount of proline compared to that of G5. Spraying of SA induced proline content in G5 and G6 leaves. G5 showed a high accumulation of proline but G6 leaves contained low amounts of proline due to SA + fusillade treatments. Leaf proline content of G5 increased with increasing basagran doses. Treatment of G6 cultivar with basagran showed no significant change of leaf proline content in comparison with that of the control. Application of SA to the highest dose of basagran enhanced more accumulation in proline content of G6 leaves.
\end{abstract}

Key words: Arachis hypogaea ; Herbicides; Proline; Salicylic acid

\section{Introdution}

Most phytotoxicological research with herbicides has been conducted on weed target plants. Little had been published concerning crop plants. Herbicides are used widely in agriculture, industry, and urban areas. However, injures in cell organelles and alteration in physiological activities of crop plants have been rising due to application of herbicides (Fayez and Kristen, 1996; Fayez, 2000).

Peanut (Arachis hypogaea, Fabaceae), is an economically important food crop in many countries worldwide. It is native to South Africa, Mexico, South America and Mediterranean region. Weeds cause tremendous damage to yields and reduce peanut yield up to $75 \%$ (Wilcut et al., 1994; Dotray and Keeling, 1997). The postemergence herbicides used in peanuts for broadleaf weed control are paraquat, 2,4- dichlorophenoxybutanoic acid, bentazon (basagran), acifluorfen, graminicides such as clethodim, fluazifop-P-butyl (fusilade) and sethoxydim (Wilcut et al., 1994).

Fusilade is globally employed as an overthe-top (blanket) spray to control a long list of perennial and annual grass weeds in a variety of situations with, reportedly, minimal damage to non-target species (Syngenta, 2006). However, research by the farmer Weed Research Organization in the UK suggested that fluazifop-p-butyl is phytotoxic to some dicotyledons including legumes (Bebb et al., 1985). The main target sit of fusilade is the inhibition of acetyl coenzyme A carboxylase activity (Parsons, 1987). Basagran herbicide is extensively used in agriculture to replace atrazine (Hourmant et al., 2009).

\footnotetext{
* Corresponding author:

Dr. Khalaf Ali Fayez

凶khalaffayez@yahoo.com
} 
Basagran, acts as an inhibitor of photosynthesis, competes with plastoquinone at its binding site on the D1 protein, blocking electron transport from photosystem II (PS II), resulting in photosynthesis inhibition and generation oxidative stress in sensitive species (Macedo et al., 2008; Reis et al., 2011). The phototoxic action of the PS II herbicides is manifest by reactive oxygen species (ROS) production (Krieger-Liszkay, 2005). Many groups of herbicides target amino acids biosynthesis (Kishore and Shah, 1998). Chlorsulfuron herbicide (sulfonylureas) induced the increase of proline content (Fayez and Kristen, 1996) and inhibited the biosynthesis of branched-chain amino acids (Ray, 1984).

Salicylic acid (SA) is an important signaling molecule in plants and induces plant tolerance to various biotic and abiotic stresses (Horvath et al., 2007; Kazemi et al., 2010). The majority of SA as a phytohormoneregulated abiotic stresses in plants is involved in antioxidant responses, thus indicating that protection of plants from oxidative damage by SA is associated with an enhanced antioxidant system and induction of biotic stress tolerance (Rao et al., 1997; Dat et al., 1998; Kogel and Langen, 2005).

Proline and other amino acids are the most common compatible solutes that occur in a wide variety of plants. They provide protections against stress by maintaining redox homeostasis, scavenging free radicals (Holmström et al., 2000; Hong et al., 2000; Okuma et al., 2000, 2004; Chen et al., 2006; Hoque et al., 2008). Increased levels of proline in plants correlate with enhanced stress tolerance (Hasegawa et al., 2000; Shah et al., 2001; Ashraf and Foolad, 2007).

The role of proline as a free radical scavenger is more important in overcoming stress than its role as a simple osmolyte (Hong et al., 2000). Proline enhances antioxidant defense systems in plant in response to various oxidative stresses (Khedr et al., 2003; Demiral and Türkan, 2004; Okuma et al., 2004; Molinari et al., 2007; Banu et al., 2009).

One of the primary limitations in this research has been the lack of tolerance to the herbicides by one of the major crops of the world; peanut. Therefore, the aim of this work was to study the action of fusilade and basagran, and salicylic acid on the total amino acids and proline of two cultivars peanut.

\section{Materials and methods \\ Plant materials and treatments}

Seeds of peanut (Arachis hypogaea, cv. Gize 5 and Giza 6), were kindly provided by the Agriculture Research Center, Ministry of Agriculture, Shandawil, Sohag, Egypt. The used herbicides were Fusilade (fluzifop-pbutyl) belongs to the aryloxyphenoxy propionate (Fops) and Basagran (bentazon) belongs to the benzothiadiazinone group of herbicides. The two herbicides were commercially available and frequently used for weed control throughout the peanut fields. The herbicides used were applied by spraying to leaves until run off.

Seeds of two cultivars of peanut were sown in a mixture of sand and clay $(1: 2, \mathrm{v} / \mathrm{v})$ in clean plastic pots. Four weeks later, plants showed the same growth were chosen, divided into groups, and treated for two weeks as the following:

Group 1, (Control, $\left.\mathrm{H}_{2} \mathrm{O}\right)$ healthy control plants was sprayed with water.

Group 2, (Control, SA) plants sprayed with $1 \mathrm{mM}$ sodium salicylate $(1 \mathrm{mM})$.

Group 3, (0.5 FD) plants sprayed with half of normal dose of fusilade.

Group 4, (1 FD) plants sprayed with normal dose of fusilade. The normal dose of fusilade $(12.5 \%$ a.i) is $12.5 \mathrm{ml} / 10 \mathrm{~L}=0.156 \mathrm{~g}$ fluazifop-p-butyle /L.

Group 5, (1.5 FD) plants sprayed with 1.5 normal dose of fusilade.

Group 6, (1.5 FD SA SP) plants sprayed by 1 $\mathrm{mM}$ sodium salicylate one day before treatment with 1.5 FD of fusilade.

Group 7, (1.5 FD SA Mix) plants sprayed by 1 $\mathrm{mM}$ sodium salicylate mixed with fusilade solution (1.5 FD).

Group 8, (0.5 FD) plants sprayed with half of normal dose of basagran.

Group 9, (1 FD) plants sprayed with normal dose of basagran. The normal dose of basagran (48\% a.i) is $25 \mathrm{ml} / 10 \mathrm{~L}=1.6 \mathrm{~g}$ betazone /L. 
Group 10, (1.5 FD) plants sprayed with 1.5 normal dose of basagran.

Group 11, (1.5 FD SA SP) plants sprayed by $1 \mathrm{mM}$ sodium salicylate one day before treatment with 1.5 normal dose of basagran.

Group 12, (1.5 FD SA Mix) plants sprayed by $1 \mathrm{mM}$ salicylate prepared in basagran solution (1.5 normal).

\section{Experimental methods \\ Total free amino acids content}

Total free amino acids were extracted from plant tissues and determined according to (Moore and Stein, 1948). To $0.2 \mathrm{~mL}$ of extract, add $1 \mathrm{~mL}$ of ninhydrin solution. Make up the volume to $2 \mathrm{~mL}$ with distilled water. Heat the tube in boiling water bath for $20 \mathrm{~min}$. Add $5 \mathrm{~mL}$ of the diluents and mix the contents. After $15 \mathrm{~min}$ read the intensity of the purple color against a reagent blank in a colorimeter at $570 \mathrm{~nm}$ against blank. The color is stable for $1 \mathrm{~h}$. The free amino acids concentrations were calculated as $\mathrm{mg} / \mathrm{g}$ dry matter.

\section{Proline:}

Content of proline in control and herbicide treated leaves were determined according to Bates et al. (1973). A known dry weight (0.1 g) of leaves was extracted in $10 \mathrm{ml}$ of aqueous $3 \%$ sulfosalicylic acid overnight. The extract was centrifuged at $3000 \mathrm{~g}$ for $10 \mathrm{~min}$. A total of $2 \mathrm{~mL}$ of the supernatant proline was mixed with $2 \mathrm{~mL}$ of fresh acid ninhydrin solution for reaction and $2 \mathrm{~mL}$ glacial acetic acid in a test tube for $1 \mathrm{~h}$ at $100^{\circ} \mathrm{C}$. The reaction was terminated in an ice bath, and the mixture was extracted with $4 \mathrm{~mL}$ toluene. The extract was vigorously stirred for $20 \mathrm{~s}$ using a test tube stirrer. Therefore, the chromophore-containing toluene was aspirated from the aqueous phase, and its absorbance was measured at $520 \mathrm{~nm}$. The proline content was determined from a standard curve and calculated on a dry weight basis.

\section{Results}

\section{Total free amino acids}

Data expressing the total free amino acids content of peanut leaves was shown in figures 1 and 2. A noticeable reduction was observed in leaves sprayed with fusilade herbicide. The degree of reduction was occurred in a gradual manner (i.e by increasing fusilade dose, the amino acids concentration decreased). Due to the highest fusilade dose (1.5 FD), the amino acid contents of G5 and G6 were reduced by $17.8 \%$ and $19.3 \%$, respectively. The amount of amino acids was higher in G5 leaves than those of G6. Treatment of plants with SA affects greatly the leaf contents of amino acids. In details, SA caused significant increase in G6 content of amino acids and non noticeable decrease in G5 content.

Application of SA by spraying a day before fusilade treatment caused a significant increase of G5 and G6 amino acid contents comparing with the corresponding controls. SA mixed with fusilade slightly decreased the amino acids content in G5 and G6 cultivars.

The results concerning basagran treatments of both cultivars were presented in figure 2. The two cultivars showed different behavior in response to basagran doses. Field dose of basagran caused accumulation of the amino acids in both G5 and G6 cultivars. This accumulation reached about $24 \%$ and $30 \%$ higher than the control in G5 and G6, respectively. In contrast, application the highest basagran dose (1.5 FD) on peanut G6 leaves resulted in reduction of amino acids level. SA treatments, mixed with or sprayed before basagran application, caused no clear changes in the contents of amino acids.

\section{Proline content:}

A test for analyzing proline contents of control and treated peanut leaves of G5 and G6 cultivars was performed and the results were presented in figures 3 and 4. It was found that, G5 and G6 leaf proline contents showed different values, G6 contained almost doubled amount of proline compared with that of G5. Without herbicide treatments, SA spray induced the accumulation of proline in G5 and G6 leaves. This induction was more obvious in G6 than in G5. Leaves of G6 cultivar responded to fusilade herbicide ( $0.5 \mathrm{FD})$ by accumulation of high amounts of proline. On the other hand, proline contents of G5 leaves treated with fusilade (0.5-1.5 FD) unaffected regardless the fusilade dose applied. The two cultivars showed different response towards SA mixed with or sprayed before fusilade 
treatments. In details, G5 showed high accumulation of proline but G6 leaves contained low amounts when leaves were treated with SA + fusilade. Basagran greatly affects the proline levels in treated leaves compared with the untreated control. The increase of proline amount was basagran dose dependant (high basagran dose caused accumulation of more proline in leaves). Application of the highest basagran dose caused accumulation of proline (double fold) in G5 leaves while proline amounts of G6 leaves showed no significant change in comparison with the control. In G5 cultivar, SA treatment adjusted the proline level to be more or less similar to that of the control. On the other side, G6 leaves treated with SA showed highly significant in proline concentrations.

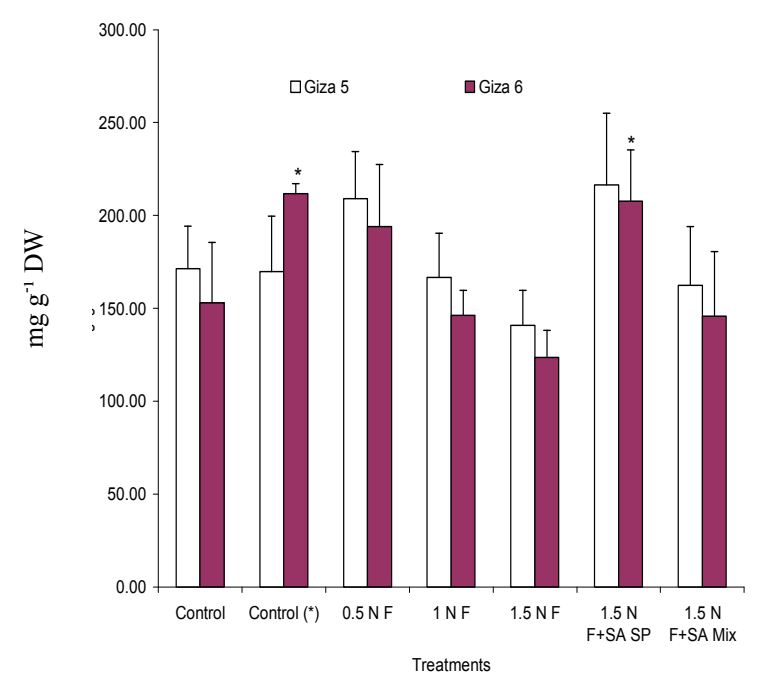

Fig. 1. Effect of fusilade and SA treatments on total free amino acids content (mg g $\left.\mathrm{g}^{-1} \mathrm{DW}\right)$ of peanut (Arachis hypogaea cv. Giza 5 and Giza 6) leaves. Values are means (M) of three replicates \pm stander deviation (SD). Statistical significance of differences compared to control: ${ }^{*}$, significant at $P<0.05 ; * *$, significant at $P<0.01$

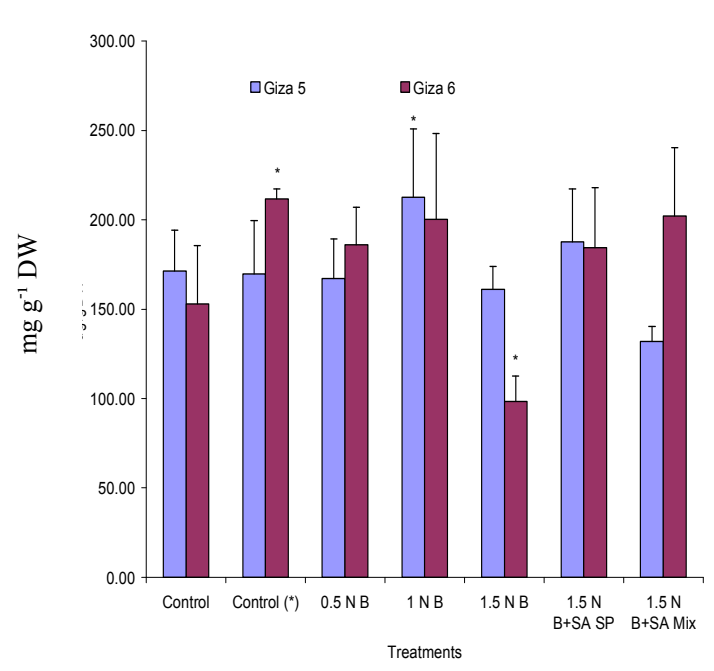

Fig. 2. Effect of basagran and SA treatments on total free amino acids content (mg g $\left.\mathrm{g}^{-1} \mathrm{DW}\right)$ of peanut (Arachis hypogaea cv. Giza 5 and Giza 6 leaves. Values are means (M) of three replicates \pm stander deviation (SD). Statistical significance of differences compared to control: ${ }^{*}$, significant at $P<0.05$; **, significant at $P<0.01$

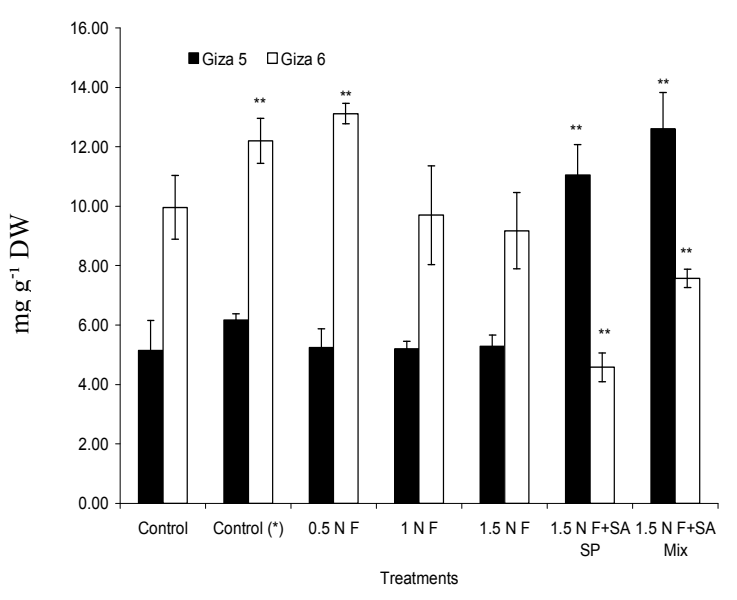

Fig. 3. Effect of fusilade and SA treatments on proline content ( $\left.\mathrm{mg} \mathrm{g}^{-1} \mathrm{DW}\right)$ of peanut (Arachis hypogaea cv. Giza 5 and Giza 6 leaves. Values are means $(\mathrm{M})$ of three replicates \pm stander deviation (SD). Statistical significance of differences compared to control: *, significant at $P<0.05$; **, significant at $P<0.01$ 


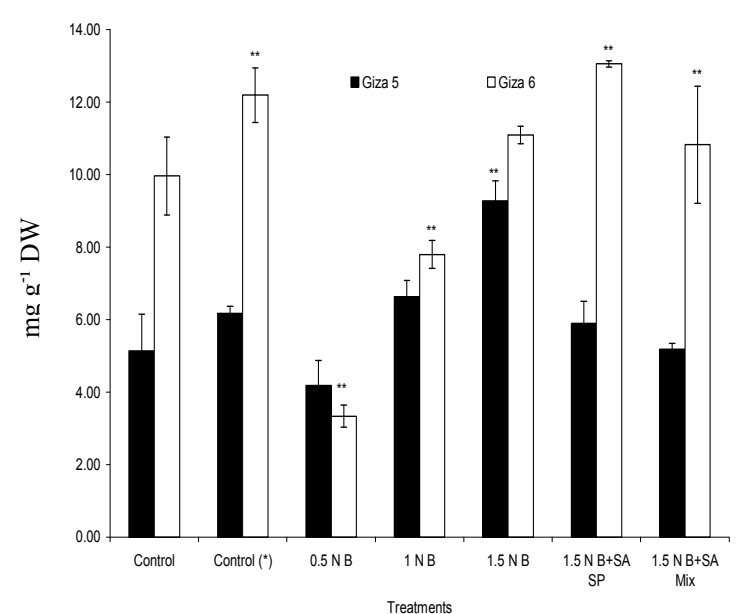

Fig. 4. Effect of basagran and SA treatments on proline content ( $\left.\mathrm{mg} \mathrm{g}^{-1} \mathrm{DW}\right)$ of peanut (Arachis hypogaea cv. Giza 5 and Giza 6) leaves. Values are means $(\mathrm{M})$ of three replicates \pm stander deviation (SD). Statistical significance of differences compared to control: *, significant at $P<0.05$; **, significant at $P<0.01$

\section{Discussion}

Free amino acids accumulate in plants by natural environmental stress; it is also accumulated in plants due to diuron herbicide stresses (Fayez, 2000; Fayez and AbdElfattah, 2007). In contrast, fusilade and basagran herbicides resulted in noticeable reduction in total free amino acids. In support to the obtained data, free amino acids content decreased considerably with fluchloralin herbicide in peanut (Arachis hypogaea) treatment (Durgesha, 1993). It is suggested that transamination reactions could be affected and the process of senescence may be enhanced (El-Taybe and Zaki, 2009).

Proline has multiple functions, such as osmotic pressure regulation, protection of membrane integrity, stabilization of enzymes/proteins, maintaining appropriate $\mathrm{NADP}^{+} / \mathrm{NADPH}$ ratios and scavenger of free radicals (Hare and Cress, 1997). As stated before in the results of this study, peanut leaves response to all treatments applied by accumulation of proline content. These results are in close with results obtained by other investigators that proline content showed a significant accumulation with increasing of herbicide concentration (Fayez and Kristen, 1996; El-Taybe and Zaki, 2009). Moreover, plant leaves experiencing biotic stress accumulating proline amounts were observed (Hare and Cress, 1997). Moreover, the increase of proline was expected since the metabolic actions of the compounds used represent severe stress situations comparable to various environmental stressors such as drought (Aspinall and Paleg, 1981)) or osmotic changes (Voetberg and Sharp, 1991). Application of SA by spraying one day before fusilade treatment caused significant increase in amino acid contents of both cultivars comparing with those of controls. While SA mixed with fusilade decreased the amino acids content of both cultivars. SA mixed with or sprayed one day before basagran application, caused no clear changes in the concentrations of amino acids. SA spray induced the accumulation of proline in both cultivars. This induction was more obvious in G6 than in G5, may be that due to G6 more resistant than G5 cultivar and more tolerance to stress. SA regulated the level of proline, total amino acids and soluble protein content in tobacco leaves (Wei et al., 2006). In plants, proline enhanced antioxidant defense systems in response to various oxidative stresses (Khedr et al., 2003; Demiral and Türkan, 2004; Molinari et al., 2007; Okuma et al., 2004; Radwan et al. 2007). This accumulation in proline contents can be explained as a defense mechanism towards stress. In summary, the results of total amino acids and proline quantifications support the hypothesis that the herbicides target weeds affect physiological activities of crop plants.

\section{References}

Ashraf, M., Foolad M.R. (2007). Roles of glycinebetaine and proline in improving plant abiotic stress resistance. Environ Exp. Bot. 59: 206-216.

Aspinall, D., Paleg, L.G. (1981). Proline accumulation : physiological aspects. Pages 205- 241 in L. G. Paleg and D. Aspinall, eds. The physiology and biochemistry of drought resistance in plants. Academic press, Sydney.

Banu, M.N.A., Hoque M.A., Watanabe-Sugimoto M., Matsuoka K., Nakamura Y., Shimoishi Y. (2009). Proline and glycinebetaine induce antioxidant defense gene expression and suppress cell death in cultured tobacco cells 
under salt stress. J. Plant Physiol. 166: 146156.

Bates, L.S., Waldern, R.P., Teare, I.D. (1973). Rapid determination of free proline for water stress studies. Plant Soil 39: 205-207.

Bebb, J.M, Greaves, M.P., Richardson, W.G. (1985). The side effects of alloxydim sodium, sethoxydim, acifluorfen and fluazifopbutyl on legume growth and nodulation. Technical Report, 81. Agricultural Research Council, Weed Research Organization, UK.

Chen, C., Wanduragala, S., Becker, D.F., Dickman, M.B. (2006). Tomato QM-like protein protects Saccharomyces cerevisiae cells against oxidative stress by regulating intracellular proline levels. Appl Environ Microbiol. 72: 4001-4006.

Dat, J.F., Lopez-Delgado, H., Foyer., C.H., Scott, I.M. (1998). Parallel changes in $\mathrm{H}_{2} \mathrm{O}_{2}$ and catalase during thermotolerance induced by salicylic acid or heat acclimation in mustard seedlings. Plant Physiol. 116:1351-1357.

Demiral, T., Türkan, I. (2004). Does exogenous glycinebetaine affect antioxidative system of rice seedlings under $\mathrm{NaCl}$ treatment? J. Plant Physiol. 161:1089-1100.

Dotray, P.A., Keeling, J.W. (1997). Purple nutsedge control in peanut as affected by imazameth and imazethapyr application timing. Peanut Sci. 24:113-116.

Durgesha, M. (1993). Effect of fluchloralin on protein synthesis, free amino acids and hydroxyproline content in groundnut (Arachis hypogaea) .Ann. applied boil. 123: 703-708.

El-Taybe, M.A., Zaki, H. (2009). Cytophysiological response of Vicia faba to glyphosate-based herbicide. AmericanEurasian J. Agronomy 2:168-175.

Fayez, K.A. (2000). Action of photosynthetic diuron herbicide on cell organelles and biochemical constituents of the leaves of two soybean cultivars. Pest. biochem. Physiol. 66: 105-115.

Fayez, K.A., Kristen, U. (1996). The influence of herbicides on the growth and proline content of primary roots and on the ultrastructure of root caps. Environ. exp. Bot. 36:71-81.

Fayez, K.A., Abd- Elfattah, Z. (2007). Alteration in growth and physiological activities in Chlorella vulgaris under the effect of photosynthetic inhibitor diuron. Int. J. Agri. Biol. 9: 631-634.

Hare, P.D., Cress, W.A. (1997). Metabolic implications of stress-induced proline accumulation in plants, Plant Growth Regul. 21: 79-102.
Hasegawa, P.M., Bressan, R.A., Zhu, J.K., Bohnert, H.J. (2000). Plant cellular and molecular responses to high salinity. Annu Rev Plant Physiol Plant Mol Biol.51: 463499.

Holmström, K.O., Somersalo, S., Mandal, A., Palva, T.E., Welin, B. (2000). Improved tolerance to salinity and low temperature in transgenic tobacco producing glycinebetaine. J. Exp. Bot. 51: 177-185.

Hong, Z., Lakkineni, K., Zhang, Z., Verma, D.P.S. (2000). Removal of feedback inhibition of D1-pyrroline-5-carboxylate synthetase results in increased proline accumulation and protection of plants from osmotic stress. Plant Physiol. 122: 1129-1136.

Hoque, M.A., Banu, M.N.A., Nakamura, Y., Shimoishi, Y., Murata, Y. (2008). Proline and glycinebetaine enhance antioxidant defense and methyl glyoxal detoxification systems and reduce $\mathrm{NaCl}$-induced damage in cultured tobacco cells. J. Plant Physiol. 165: 813-824.

Horvath, E., Szalai, G., Janda, T. (2007). Induction of abiotic stress tolerance by salicylic acid signaling. J. Plant Growth Regul. 26: 290300 .

Hourmant, A., Amara, A., Pouline, P., Durand, G., Arzul, G., Quiniou, F. (2009). Effect of bentazon on growth and physiological responses of marine diatom: Chaetoceros gracilis. Toxicol. Mechan. Methods. 19: 109115.

Khedr, A.H.A., Abbas, M.A., Wahid, A.A.A., Quick, W.P., Abogadallah, G.M. (2003). Proline induces the expression of salt-stress responsive proteins and may improve the adaptation of Pancratium maritimum L. to salt-stress. J. Exp. Bot. 54: 2553-2562.

Kishore, G.M., Shah, D.M. (1998). Amino acid biosynthesis inhibitors as herbicides. Annu. Rev. Biochem. 57: 623-663.

Kogel, K.H., Langen, G. (2005). Induced disease resistance and gene expression in cereals. Cell Microbiol. 7: 1555-1564.

Krieger-Liszkay, A. (2005). Singlet oxygen production in photosynthesis, J. Exp. Bot. 56: 337-346.

Macedo, R.S., Lombardi AT, Omachi CY, Rörig LR (2008). Effects of the herbicide bentazon on growth and photosystem II maximum quantum yield of the marine diatom Skeletonema costatum. Toxicol. In vitro 22: 716-722.

Molinari, H.B.C., Marur, C.J., Daros, E., de Campos, M.K.F., de Carvalho J.F.R.P., Filho, J.C.B. (2007). Evaluation of the stress- 
inducible production of praline in transgenic sugarcane (Saccharum spp.): osmotic adjustment, chlorophyll fluorescence and oxidative stress. Physiol. Plant. 130: 218-229.

Moore, S., Stein, W.W. (1948). Photometric ninhydrin method for use in the chromatography of amino acids. J. Biol. Chem. 176: 367-388.

Kazemi, N., Khavari-Nejad, R.A., Fahimi, H., Saadatmand, S., Nejad-Sattari, T. (2010). Effects of exogenous salicylic acid and nitric oxide on lipid peroxidation and antioxidant enzyme activities in leaves of Brassica napus L. under nickel stress. Scientia Horticulturae 126: 402-407.

Okuma, E., Murakami, Y., Shimoishi, Y., Tada, M., Murata, Y. (2004). Effects of exogenous application of proline and betaine on the growth of tobacco cultured cells under saline conditions. Soil Sci. Plant Nutr. 50:13011305.

Okuma, E., Soeda, K., Tada, M., Murata, Y. (2000). Exogenous proline mitigates the inhibition of growth of Nicotiana tabacum cultured cells under saline conditions. Soil Sci. Plant Nutr. 46: 257-263.

Parsons, J.M. (1987). Australian Weed Control Handbook, eighth ed. Inkata Press, Port Melbourne, Australia.

Radwan, D.E.M., Fayez, K.A., Mahmud, S.Y., Hamad, A., Lu, G. (2007). Physiological and metabolic changes of Cucurbita pepo leaves in response to zucchini yellow mosaic virus (ZYMV) infection and salicylic acid treatments. Plant Physiol. Biochem. 45: 480489.

Rao, M.V., Paliyath, G., Ormrod, D.P., Murr, D.P., Watkins, C.B. (1997). Influence of salicylic acid on $\mathrm{H}_{2} \mathrm{O}_{2}$ production, oxidative stress, and $\mathrm{H}_{2} \mathrm{O}_{2}$ metabolizing enzymes (Salicylic AcidMediated Oxidative Damage Requires $\mathrm{H}_{2} \mathrm{O}_{2}$ ). Plant Physiol. 115: 137-149.

Ray, T.B. (1984). Site of action of chlorsulfuron: Inhibition of valine, leucine and isoleucine biosynthesis in plants, Plant Physiol. 75: 827831

Reis, M.O., Necchi, Jr O., Colepicolo, P., Barros, M.P. (2011). Co-stressors chilling and high light increase photooxidative stress in diurontreated red alga Kappaphycus alvarezii but with lower involvement of $\mathrm{H}_{2} \mathrm{O}_{2}$. Pest. Biochem. Physiol. 99: 7-15.

Shah, K., Kumar, R.G., Verma, S., Dubey, R.S. (2001). Effect of cadmium on lipid peroxidation, superoxide anion generation and activities of antioxidant enzymes in growing rice seedlings. Plant Sci. 161: 11351144.

Syngenta, (2006). Fusilade Fact Sheet. $<$ http://www.sygenta.com/en/products_servic es/ fact_sheets/fusilade_window.html $>$ retrieved 13.06.06.

Voetberg, G.S., Sharp, R.E. (1991). Growth of the maize primary root at different water potentials. III Role of increased proline deposition in osmotic adjustment. Plant Physiol. 96: 1125- 1130.

Wei, X., Wang, L.M., Long, R.J., Wang, G.X. (2006). effects of exogenous nitric oxide, salicylic acid and hydrogen peroxide on free amino acid and soluble protein contents in tobacco leaves. Zhi Wu Sheng Li Yu Fen Zi Sheng Wu Xue Xue Bao 32: 257-260.

Wilcut, J.W., York, A.C., Wehtje, G.R. (1994). The control and interaction of weeds in peanut. Rev. Weed Sci. 6: 177-205. 